\title{
Considerations for large-diameter raiseboring
}

\author{
RR Lyle Cementation Canada Inc., Canada
}

\begin{abstract}
For over 50 years, raisebore drilling technology has been successfully employed for vertical mine development in mines around the world. In the early days, raiseboring was limited to small-diameter ( $2 \mathrm{~m})$ raises; but with time the method has evolved so that boreholes greater than $5 \mathrm{~m}$ are now routinely completed without incident. One important evolution is the Rotary Vertical Drilling System (RVDS) to maintain verticality of boreholes. This technology enables the effective development of hoisting shafts using accurately controlled vertical raisebored excavations.

Mine planners must now consider using raiseboring techniques not only for small-diameter raises, but for large-diameter vertical development, including ventilation, secondary egress and hoisting shafts. This paper provides insight into the important considerations for large-diameter raiseboring projects. This includes an examination of methods to assess geotechnical risk for large-diameter raiseboring projects, including the commonly employed McCracken and Stacy (1989) method. Examples of recent, prominent large-diameter raiseboring projects are also profiled to show the diverse range of projects which have been able to take advantage of modern raisebore technology.
\end{abstract}

Keywords: vertical mine development, raiseboring, mine planning, borehole hoisting

\section{Introduction}

\subsection{Background, outline and objective}

Raiseboring techniques have been used for over 50 years to efficiently open up vertical development in mines around the world. The technology has evolved with time through increases in the possible range of raise diameter and length, verticality, and productivity. Consequently, the list of applications of long, vertical, large-diameter raiseboring continues to grow. Borehole hoisting applications were first used in the 1970s with small-diameter raise excavations used for hoisting. These have evolved into the large-diameter, high-production borehole hoisting shafts of today.

This paper provides a brief description of the raiseboring method, its applications, key considerations and enabling technologies. The paper culminates with a series of short, descriptive narratives on recent, prominent large-diameter raiseboring projects, showing the varied applications of the method. The paper is arranged in the following sections:

- Introduction, including method description and concise history of the technique.

- General considerations for the method.

- A more detailed discussion of the key ground/geotechnical considerations.

- A brief description of prominent large-diameter raiseboring projects.

The overall objective of this paper is to illustrate the fact that raiseboring technology has sufficiently advanced so that large-diameter raises are now frequently successfully completed without mechanical incident or in-hole hardware failure. As the most significant technical risks to any large-diameter raiseboring project are those presented by geological and geotechnical conditions, specific attention is given to considerations of ground suitability. 


\subsection{The raiseboring method}

Raiseboring is a method to develop vertical openings using a drilling machine from an upper level. It requires access to a top location (either surface or underground) and a bottom breakthrough location. The method begins by drilling a pilot hole (various sizes, generally $280-450 \mathrm{~mm}$ ) to intersect the opening at depth. The pilot drill bit is then removed and replaced with a reaming head (of various sizes, up to $8+m$ have been designed). The drill now applies rotation and thrust (upwards) to the reamer through significant torque and tension on the drill rods. The excavation then proceeds from the bottom up. Cutter discs/inserts describe circles in the rock face, and the rock fails primarily in shear, forming small chips of rock. The rock cuttings fall through the reamer openings by gravity to the raise bottom, where the muck must be continually removed.

The general raiseboring reaming process is shown in Figure 1(a), while a raise drill and rods are shown in Figure 1(b), a reamer at raise bottom (Figure 1(c)) and at surface breakthrough (Figure 1(d)) are also shown.
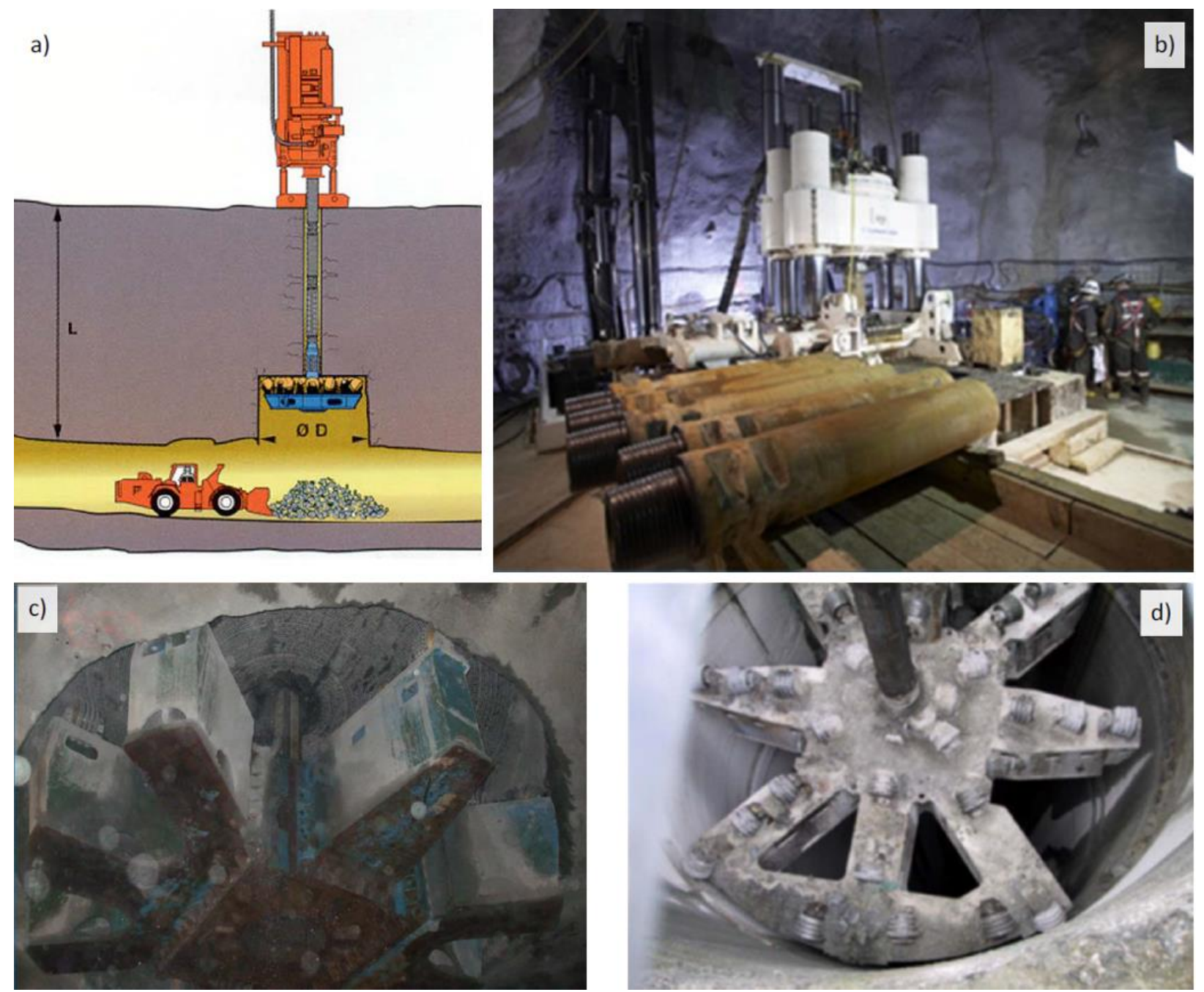

Figure 1 (a) Raiseboring schematic showing reaming phase (from Ferreira 2005); (b) Typical underground raise drill set-up with drill rods in foreground; (c) Reamer at raise bottom; and, (d) Reamer breaking through to surface (photos courtesy of Cementation Canada) 


\subsection{History of the raiseboring technique}

An excellent overview of the early history of raiseboring technology is given by Stack (1982); a brief summary follows. The earliest breakthrough in raiseboring came in 1949 when Mr Bade, a German engineer, pioneered a raise machine consisting of a rope winch, a borer and a control point. Hydraulic propulsion jacks were used to push upwards on the rotating borer using steel cutters. The winch was used to support the borer while the jacks repositioned after fully extending. These early machines were successfully used to develop approximately $1.5 \mathrm{~m}$ diameter raises at German iron and coal mines for many years.

The development of the first raiseboring machines akin to modern machines (as described in Section 1.2) came in the late 1950s by Robert Cannon and the Robbins Company in the USA. The Cannon/Robbins raise drill was tested and modified with use at the Hanna Mining Company in Michigan, and Inco Nickel mines in Sudbury, Ontario in the early to mid-1960s. By the end of the decade, the raiseboring method was a well-accepted method for raises up to $1.8 \mathrm{~m}$ in diameter and $250 \mathrm{~m}$ long.

By 1971, Mount Isa Mines in Queensland, Australia began development of a raiseboring program. The technology gained wide acceptance and evolved sufficiently in Australia to become the preferred option for any vertical development.

Raiseboring started to be used in South Africa by 1968 where machines were capable of drilling $1.2 \mathrm{~m}$ diameter raises up to a length of $90 \mathrm{~m}$ (Oosthuizen 2004). With the favourable ground conditions and well-developed expertise in South Africa, large-diameter $(>4.5 \mathrm{~m}$ ) raiseboring projects were successfully completed there in the 1980s and 1990s. Comparable projects in North America were not realised until the last decade.

\subsection{Raiseboring applications}

Excavations completed by the raiseboring method are commonly used in mining projects for ventilation corridors, rock passes (ore or waste), access between mine levels or as a secondary egress. Bored raises are also used in civil works for vertical development in hydroelectric schemes, transportation and water works projects.

Raisebored hoisting shafts have been used since the early 1970s when the Tynagh lead-zinc mine in Ireland established a $2.1 \mathrm{~m}$ diameter hoisting shaft (Dengler \& Brown 1976). Other bored hoisting shafts developed in the 1970s include a $3.6 \mathrm{~m}$ diameter shaft at the Cayuga Salt Mine, USA (Goodman et al. 2009) and a $2.1 \mathrm{~m}$ temporary hoisting shaft used during shaft sinking and mine development at Brunswick Mines, Canada (Dengler \& Brown 1976). Of these three hoisting plants, only the Cayuga Shaft remains in operation to date.

As noted by Hudd and Martin (2010) large-diameter raiseboring has been traditionally considered to be $3.6 \mathrm{~m}$ diameter holes up to $300 \mathrm{~m}$ long. This same diameter was noted by McCracken and Stacey (1989) as a typical large diameter in 1980s, though they also note that raises in excess of $6 \mathrm{~m}$ were possible (likely referring to South African experience). As raiseboring has evolved to allow larger diameter raises, comparable to traditional blind sinking shafts, true mine shafts - suitable for running hoisted conveyances - can now be constructed using the raiseboring method. Examples include Canada's Young-Davidson mine $-5.5 \mathrm{~m}$ diameter, $\sim 1,500 \mathrm{~m}$ deep when complete (Martin et al. 2012) and the Mindola Deeps project in Zambia which is currently under construction $-6.1 \mathrm{~m}$ diameter, $\sim 2,000 \mathrm{~m}$ deep (Sidler 2014).

Other commonly used excavation methods for completing vertical development include blind shaft sinking, traditional raising, mechanical raise climber excavation (commonly referred to as Alimak raising), drop/longhole raises, and pilot and slash developments where a small-diameter raise is first driven (by raisebore or raise climber methods) and then slashed out to full diameter from the top down. Other, less commonly employed methods include blind drilling and the mechanical V-mole (see Oosthuizen 2004). A comparison of the merits of all these methodologies is beyond the scope of this paper, but a comparison of the main advantages and disadvantages of the raiseboring method is given in Table 1. 
Table 1 Advantages and disadvantages of the raiseboring method (based on Harrison et al. 1972; McCracken \& Stacy 1989; Nadon \& Kelly 1991; Ferreira 2005; Hudd \& Martin 2010)

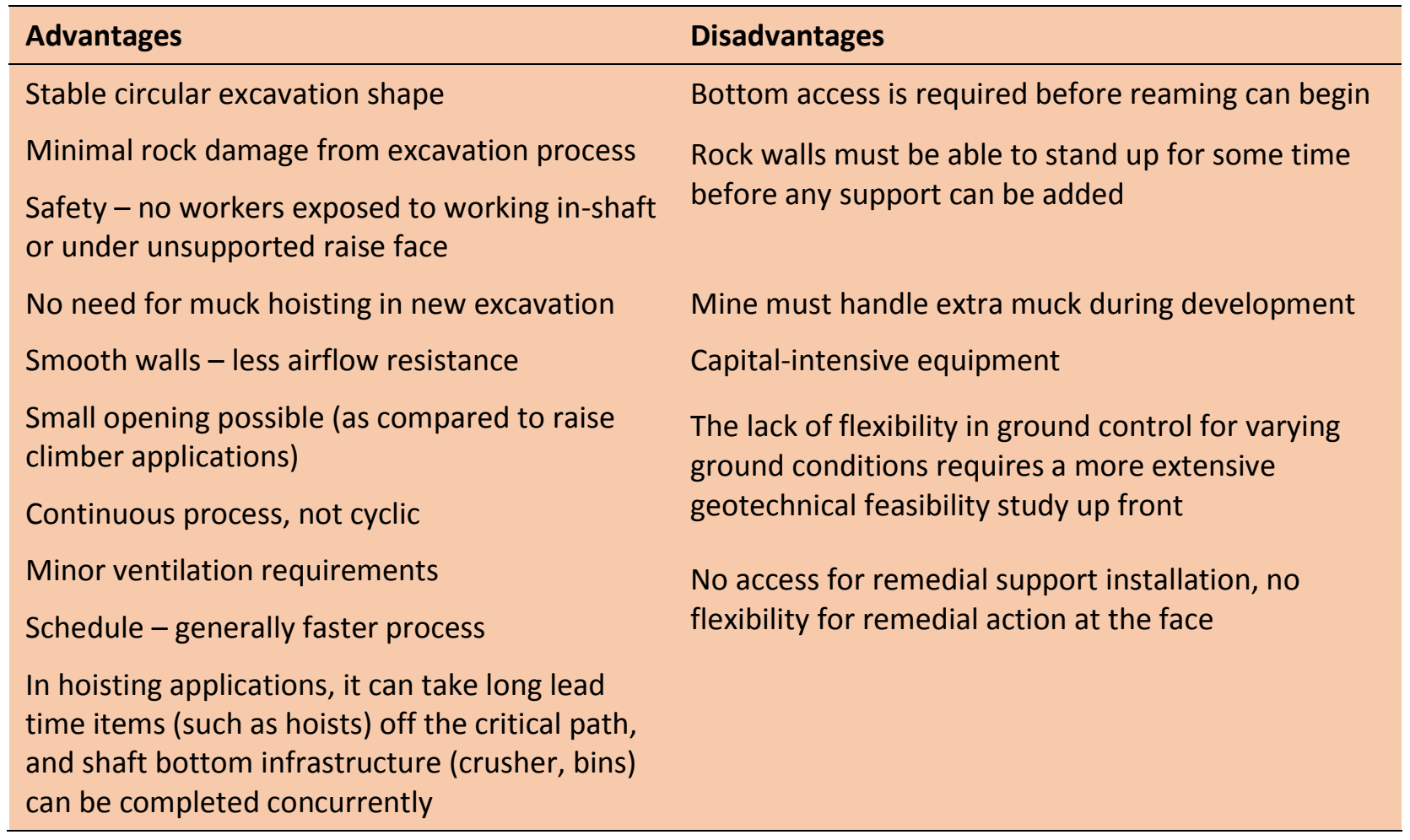

\section{$2 \quad$ Large-diameter raiseboring considerations}

\subsection{Introduction}

This section provides introductory insight into some of the key technical considerations for large-diameter raiseboring projects. It is not exhaustive and does not contain much operational or safety-related details. For more detailed information on the entire raiseboring process, see the comprehensive Guideline for Raiseboring Operations produced by New South Wales (NSW) Mine Safety (2013).

\subsection{Fundamental questions when considering raiseboring}

Hudd and Martin (2010) list four key questions to ask when considering large-diameter hard rock raiseboring:

A 'yes' answer is required for all four questions in order for raiseboring to be a viable option.

- Is the size and length within current capabilities? Generally speaking, the raise must be no longer than $1,000 \mathrm{~m}$ and no larger than $6.1 \mathrm{~m}$ in diameter. Longer raises can be completed if divided into shorter, manageable sections. Some rock types will allow larger diameter raises - such as the $7 \mathrm{~m}$ raises bored in South African coal mines (Oosthuizen 2004).

- Is the ground suitable? Raiseboring is a remote method that does not allow ground improvement as the work progresses. The ground must be of sufficient quality for sidewall stability and standup time. In addition, groundwater inflows must be manageable. In some limited applications, ground improvement 'pre-support' such as grouting, and/or contiguous piles have been successful to control water, or improve near-surface ground conditions. Remote shotcrete machines have been used successfully to stabilise ground with short stand-up time. However, it must be acknowledged that there are some ground types that are simply not amenable to large-diameter raiseboring. 
- Do you have access at the bottom? Bottom access is a prerequisite in order to remove the drill bit and install the reamer. The method is only applicable in areas that already have some development.

- Can you handle the waste generated underground? Large-diameter raiseboring projects will produce a significant amount of muck. For example a $5.5 \mathrm{~m}$ diameter ream may progress at $0.5 \mathrm{~m}$ per hour - this equates to $12 \mathrm{~m}^{3}$ in situ volume or \pm 35 tonnes per hour of waste.

\subsection{Key considerations}

This section builds upon the discussion from Hudd and Martin (2010) to address key points that require consideration when setting up a large-diameter raiseboring project. One fundamental consideration, which presents the greatest risk to any raiseboring project, is ground stability - this is discussed later in Section 3. The key considerations for raiseboring projects listed in the following sections are generally within the control of the project team, unlike the ground conditions.

\subsubsection{Access}

Proper access to the top and bottom workings is vital to the success of any raiseboring project. Access and set up can be more complicated than executing the raise drilling itself. If top access is on-surface, proper siting is important. A suitable and not insignificant pad and laydown area are required. The raise collar can be a significant project in its own right, especially in areas with considerable thickness of overburden.

For underground set-ups, a suitable raise drill chamber is required. The excavation required is dependent upon the drill used and the number of drill rods required, but a typical set-up for a large-diameter raise drill rig is $8 \times 15 \mathrm{~m}$ and $8 \mathrm{~m}$ high. The high back may only be needed in the immediate vicinity of the drill.

The requirements for the bottom access or breakthrough chamber include not only sufficient space for bit removal and reamer installation, but also to safely remove muck. Ideally, the breakthrough chamber will be located sideways to the mucking drift - allowing muck flows into the drift such that mucking operations need not turn into the muck pile.

Transportation of the drill, reaming head and drill rods is another important consideration - these are large, heavy pieces of equipment to be moved around. For instance, a large-diameter reaming head may weigh in excess of 40 tonnes and requires two tractor trailers to transport to site. Once onsite, it needs to be moved in parts to the underground breakthrough chamber for assembly, all of which can be a logistical challenge.

In addition to the access for equipment, access for raise drill operators and raise waste muckers needs to be considered. Shift schedules and central blast windows can impact the availability of both drill and mucking crews. The best drilling and reaming results are obtained from continuous, uninterrupted operations.

\subsubsection{Services - electricity, water, sumps and rod handling}

Electrical power requirements for large raise drills can be considerable - in the order of 1,000 kVA. Generators are often used in surface applications.

Water, as a bailing medium for cuttings, is required during pilot drilling. The amount of water required is dependent on groundwater conditions, but water requirements of 1,200 litres per minute are common. As with any drilling operation, circulation water can be lost or gained to the rock formation. Raise drills are not commonly set up for grouting, and casing is not tolerable for later reaming operations. Decanting sumps and settling tanks are used to be able to recycle water.

The most expensive item in raise drilling is neither the drill nor the reaming heads, but the string of drill rods. Drill rods vary in diameter and length ( 1.5 to $3 \mathrm{~m}$ ); a single rod can weigh $700 \mathrm{~kg}$ or more. Given that a typical project may require 400 rods, handling and storage are important logistical considerations. 


\subsubsection{Waste handling}

Two streams of waste are created by the raiseboring method - pilot hole drill cuttings at the top station and reaming muck at the bottom station. Pilot hole drill cuttings are flushed with water, and drill water is usually reused, as discussed previously. Each project requires a means to dispose of the solids (cuttings).

As mentioned previously, reaming muck production volumes can be quite high - large-diameter raises can generate over 40 tonnes per hour. Disposal of this muck can be problematic, and this is a very important aspect for the mine to address for the efficient execution of the work. One of the most common delays in raise projects is being 'muck-bound' when reaming operations are slowed due to mucking waste.

\subsubsection{Verticality}

Drillhole deviation is the unintended departure of the drill bit from the desired drilling path. Pilot holes for large-diameter raises should be straight, with the most favourable orientation being vertical. Verticality is more important as raise diameters increase. Unfortunately, raise pilot holes are prone to deviate like any other drillhole - they will tend to deviate in a similar fashion to exploration diamond drillholes. Deviation is generally a function of the in situ rock properties, geological structure and different drill parameters.

It is recommended (often essential) that large-diameter raisebore holes should be constructed vertically. Vertical holes are the best orientation for both efficient reamer operation and for ground stability. Vertical holes also make raise bottom development efficient, as the final raise bottom location is foreseeable. Past experience with pilot hole deviation meant unpredictable development - 'hunting' at the raise bottom to find the actual drillhole position, leading to project delays and additional costs. In addition to the aforementioned advantages, verticality is essential for raises to be used for hoisting.

A variety of pilot hole steering methods have been attempted over the years (Nadon \& Kelly 1991). The most effective and commonly used method today is the MICON Rotary Vertical Drilling System (RVDS). The system was originally developed in the early 1990s in Europe for the continental deep drilling project (Hudd \& Martin 2010). MICON and Murray and Roberts RUC worked together to modify the RVDS for largediameter raise drill pilot holes (Oosthuizen 2004).

The RVDS operates making verticality adjustments by itself, automatically. RVDS uses three main components - energy, steering and communications. Energy for the system comes from a small electric turbine within the tool powered by the flow of flushing drilling fluids. The turbine generates hydraulic power for steering and powers the sensor and data storage units. Inclinometers continuously measure the deviation of the vertical borehole axis. Automated corrections are performed by four hydraulically activated extendable steering ribs to correct against non-vertical tendencies. The unit sends data via sonic pulses through the drilling fluid to the raise collar where the operator can monitor in real time and check for malfunctions. The RVDS unit is shown in Figure 2.

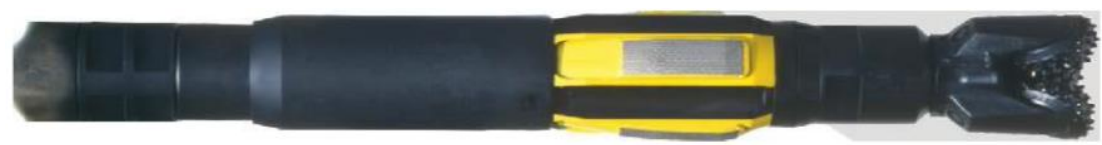

Figure 2 MICON RVDS unit (from Martin et al. 2012)

Early Canadian users of the RVDS found it susceptible to damage in hard rock. For instance, Schrami and Schimper (2002) indicate that five tools were consumed when drilling a $427 \mathrm{~m}$ pilot hole at the Red Lake mine, Ontario. It has since proved more reliable and only a single tool is generally required for a given hole.

\subsubsection{Drillability}

There are a number of factors that determine the drillability (capacity to be drilled) of the ground. The intact rock strength (unconfined compressive strength - UCS) is commonly available and used to gauge drillability. Other factors include geological structure (jointing and bedding), schistosity and abrasiveness. The impact of geological structure on drilling operations is dependent on orientation and spacing. Heavily 
jointed rock is often easier to drill, with the structure providing more free faces. Conversely, structurally controlled blocks of intact rock can lead to block or wedge instability, in turn causing the head to jam and be problematic for hole stability. Mica layers in schistose rocks can absorb some of the energy of the drilling process in a plastic process rather than the desired brittle failure, slowing reaming progress. Highly abrasive rock causes premature cutter wear - slowing drilling rates and necessitating more frequent cutter changes, reducing reaming efficiency. The abrasiveness factor is generally related to the rock's silica content. Silica content and UCS values, being generally available information, are commonly used by operators to assess the drillability for any particular project.

\section{Ground considerations}

\subsection{Background}

The second fundamental question listed in Section 2.2 - is the ground suitable? This is not always easy to answer, for as noted by Sidea and Pfitzner (2012), the most significant risks in raiseboring projects are geological and geotechnical in nature. It has been said that 'you can only take what the ground will give' and this becomes more apparent as raise diameters increase.

The main geotechnical and geological factors affecting raise stability/risk are similar to other excavation types and include (list based on McCracken \& Stacey 1989):

- Lithology - rock characteristics, weathering, and bedding.

- Major geological features - faults, folds, dykes, and contacts.

- Rock fabric - discontinuities, orientation, spacing, and persistence.

- Strength of discontinuity features - joint roughness, infill, alteration, and water.

- Intact rock strength, both fresh and weathered, and rate of weathering.

- In situ stress and changes in stress.

- Groundwater conditions.

Stability was generally much less of an issue with most early raiseboring efforts, as the small-diameter $(<2 \mathrm{~m})$ holes are inherently more stable. As more and larger diameter raises were completed, various modes of rock failure became evident. General types of stability difficulties for raiseboring excavation include:

- Wedge failure/overbreak. This can occur from the face onto the reamer head during boring or from the raise walls. Face wedge can be an immediate problem to a raise project as blocks falling on the reamer head can lead to variable loading on the rods, slow advance rates or lead to premature wear on the cutters. Wall overbreak may impact the final use of the raise, and it may be necessary to later add ground support - often remotely applied shotcrete.

- Unravelling (uncontrolled overbreak or caving). It is possible that the excavation can lead to severe unravelling, resulting in the loss of the reaming head, rods and even the raise. Where raises have been completed with large unravelling sections, remedial work is often required.

- Squeezing ground. Generally driven by high wall stresses, squeezing is the process of deterioration and dilation of weak rock with small movements along numerous joints. The process may occur quickly and can cause reaming issues.

- Swelling ground. This refers to a volume change in rock generally due to changes in moisture content in clay-rich rocks, and can be related to stress relief.

- Stress-induced fracturing/spalling. In more massive rock, stress-driven fracturing dominates failure processes. These processes may impact the reamer. 
- Time-dependent deterioration. This deterioration tends to occur due to weathering and sensitivity to changes in moisture brought on by the exposure of the rock to the environment by raiseboring. Additionally, changes in stress due to mining or deformations due to mining can be important contributing factors.

Figure 3 illustrates the common modes of failures in a raiseboring excavation.

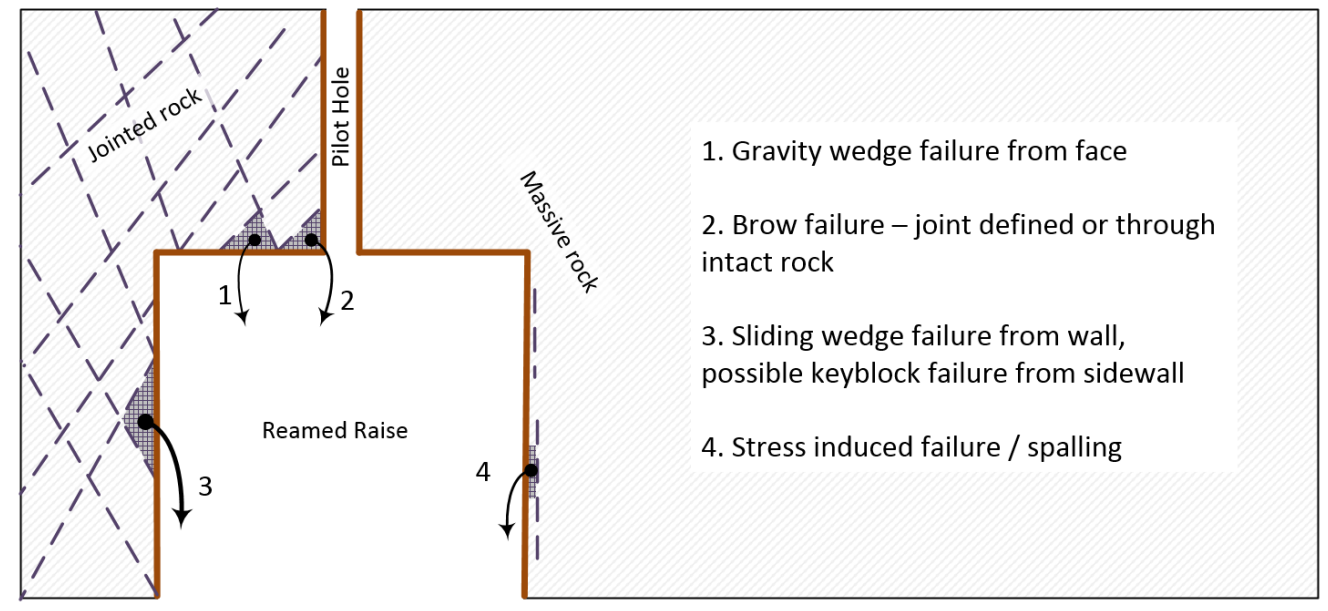

Figure 3 Possible modes of wall and face failure (based on Figure 2 from McCracken \& Stacey 1989)

One other aspect of ground suitability is the groundwater conditions. If the pilot hole intercepts a major aquifer, it could uncontrollably convey significant water to the mine below, perhaps catastrophically, especially in the case of salt and potash mines. In other environments, water inflow may deteriorate rock conditions below, or may be a safety issue for the mucking of the reamer waste.

\subsection{McCracken and Stacey (1989) geotechnical risk assessment method}

As raiseboring diameters were increasing and raise stability and risk became more questionable, the need for a systematic method of assessing the geotechnical risk became apparent. In 1989, McCracken and Stacey published their geotechnical risk assessment for large-diameter raisebored shafts (herein referred to as the M\&S Method). They recognised that rock mass classification systems developed for tunnelling stability generally contained similar factors as for raisebore stability (factors listed in Section 3.1). Therefore, they proposed to use the well-established Norwegian Geotechnical Institute's Tunnelling Quality Index (the Q-system developed by Barton et al. 1974) and modified it for raisebore stability use. This culminated in the raisebore rock mass quality index, $Q_{R}$ :

$$
\begin{gathered}
Q_{R}=\left(\frac{R Q D}{J n} \times \frac{J r}{J a} \times \frac{J w}{S R F}\right) \\
\times \text { Adjust }_{\text {wall }} \times \text { Adjust }_{\text {orientation }} \times \text { Adjust }_{\text {weathering }}
\end{gathered}
$$

where the upper line is taken from the Q-system, which is multiplied by three factors on the lower liner as specified by the M\&S Method, the parameters are defined by Barton et al. (1974) and McCracken and Stacey (1989) - in short, RQD is the rock quality designation, Jn is joint set number, Jr is joint roughness number, Ja is the joint alteration number, Jw is joint water factor and SRF is the stress reduction factor. The $\mathrm{RQD} / \mathrm{Jn}$ is an estimate of rock block size, Jr/Ja provides an indication of joint shear strength while the $\mathrm{JW} / \mathrm{SRF}$ indicates active stress conditions surrounding the excavation. The adjust factors were introduced in the M\&S Method to account for conditions specific to raiseboring; these include factors for sidewall, face orientation (to dominant persistent discontinuities) and weathering potential of the rock mass.

The maximum stable raise diameter $\left(\operatorname{span}_{\max }\right)$ is then related to the raiseboring rock mass quality index by the following relationship:

$$
\operatorname{span}_{\text {max }}=2 \times R S R \times Q_{R}^{0.4}
$$


where RSR is a risk term, which the authors set to 1.3 for typical raiseboring projects. The basis for this is not clearly defined. The $Q$-system is an empirical system for tunnels based on a database of projects with performance data. This contrasts with the $Q_{R}$ system that was developed at a time when large-diameter raiseboring was in its infancy and, correspondingly, did not have the luxury of a database of performance data. In this sense, the M\&S Method can be considered an expert judgement system rather than a true empirical approach.

The M\&S Method is the most commonly used method to assess raiseboring stability. As noted by Peck and Lee (2008), the application of the M\&S Method, like the Q-system itself, is not straight forward, and it is not necessarily used in a consistent manner by geotechnical practitioners around the world. Many practitioners have noted shortcomings in the method (Bertuzzi \& Wallis 2008; Peck \& Lee 2008; Sidea \& Pfitzner 2012, etc.), but the M\&S Method, like other empirical geotechnical design techniques, is intended to provide an indication of overall geotechnical feasibility, through a simple manner of predicting probability of failure. McCracken and Stacey (1989) conclude that "... all excavation must be considered individually and the potential problems should be addressed on merit... the method does not replace the necessity for classical analysis to evaluation of the incidence and stability of potential failure wedges".

\subsection{Updates based on Australian experience}

Peck and Lee $(2007,2008)$ compiled a database of Australian raiseboring experience to compare to the M\&S Method, providing performance data that was not available when the method was first developed. Coombes et al. (2011) and Peck et al. (2011) provided a further update with a database of 56 case histories based on their experience and information supplied by the Eastern Australian Ground Control Group. This has led to an update of the method, as well as alternative approaches to look at large-diameter raisebore stability.

Coombes et al. (2011) and Peck et al. (2011) drew various conclusions from the review of performance data and the M\&S Method. One key finding was that the general raise stability is primarily a function of rock mass blockiness - i.e. RQD/Jn and much less sensitive to the shear resistance factor Jr/Ja. This demonstrates the need to appropriately measure RQD and assess Jn. The SRF value is also key to the evaluation, and it is noted that high SRF values do not guarantee raise collapse. The authors recommend that the SRF value be obtained from Figure 2.14.7 in Hutchinson \& Diederichs (1996) review of the Q method. For the case studies compiled, no raises collapsed with $Q_{R}$ values greater than 0.3 . The paper also provides suggestions on the approach to borehole logging, in order to obtain valuable (and more repeatable) results.

In addition to adding empirical data to the M\&S Method, Peck and Lee $(2007,2008)$ recognised that the $Q$ and M\&S Methods address only the initial stability, but not stability with time. Thus, they proposed a method for assessing the stand-up time of bored excavations. A relationship between stand-up time and maximum span of horizontal development was developed for the Rock Mass Rating (RMR) system (Bieniawski 1989). For use in raiseboring applications, the modified RMR relationship for machine-bored tunnels developed by Lauffer (1988) should be used. The database of Australian raiseboring case histories was plotted on the RMR stand-up time versus span charts in Coombes et al. (2011), as well as Peck et al. (2011). Two key trends were noted from the plots - below an RMR of 30, all raises either collapsed or experienced overbreak and where RMR was greater than 40 , no raises collapsed though there were some cases of overbreak.

The database includes few examples (three or four) of raiseboring projects greater than $5 \mathrm{~m}$ diameter; most projects fell within the 3-5 $\mathrm{m}$ diameter range. It was reported that more/better data is required to improve the relationships for raiseboring stability predictions.

\subsection{Other raiseboring performance data}

The author is not aware of any collection of raiseboring stability performance data to compare to the Australian experience discussed. To improve on the reliability of the M\&S Method and the stand-up time assessment (Coombes et al 2011; Peck \& Lee 2007), a larger database, including projects outside of Australia, should be compiled. This would include additional large-diameter raises, such as those completed in the 
Republic of South Africa (RSA) and those undertaken in the past seven years since the database was compiled. Such a compilation is challenged by the fact that many raise projects do not include sufficient site investigation to acquire the necessary rock mass classification data. This is all too common in North American experience where projects often forgo site investigation expenses - sometimes for good reason, where local experience shows the ground to be suitable, and sometimes due to overconfidence in the ground conditions.

\subsection{Other methods of analysis}

One method that has been successful in assessing the suitability and stability of large-diameter raiseboring in a given location, is based on the assessment of experience/history of vertical rock exposures in the area. Nearby shafts, ramps, horizontal development and even open pit walls can all provide practical firsthand performance data for assessing raise stability. This type of judgement may be limited in new developments but for many well-developed mines, the intrinsic assessment by experienced site personnel should not be overlooked.

Kinematic analysis is often undertaken to assess wedges/blocks that are likely to be formed on the edge of raise excavations. Such analysis is relatively straightforward and commonly applied.

The M\&S Method and wedge analysis assume that rock is at least moderately jointed. Raises in massive rock are generally stable unless there are stress-related issues. With higher stress, different analysis is required to look at the impact of stress-induced fracturing and related instabilities in these cases. Stacey and Harte (1989) and O'Toole and Sidea (2005) detail stress and risk analysis for raiseboring in highly stressed rock.

Another condition to be aware of is contrasting face conditions - for example, where part of the face includes a steeply dipping, strong dyke intruding much weaker rock. The reamer head may become unbalanced in this situation causing tilting and damage or failure of the reamer/rods (Peck \& Lee 2008). This condition may be missed in site investigations but may be inferred from the geological model or experience in other mine developments.

\subsection{Discussion}

There are many factors in play in assessing the ground suitability for large-diameter raiseboring projects. One key factor for successful assessment of large-diameter raise projects includes appropriate site investigation. Site investigation requirements will vary from project to project. Raise location selection should not only include mine engineering requirements, but also incorporate the mine geological model to find ground suitable to raise stability. Once the most suitable locations are found, Coombes et al. (2011) provide solid guidance on geotechnical borehole logging for use at the project site.

Geotechnical stability reports for raiseboring often deal exclusively with the rock mass classification data without even mention of rock types. This makes it difficult to interpret weathering, squeezing, swelling, or background on persistent joint sets (bedding? schistosity?). Practitioners need a wider view that should go beyond the M\&S Method to assess raiseboring projects.

Geotechnical practitioners should also include input from raise drill operators when making judgements on ground suitability. For instance, comments such as 'operator to ensure that cutter will not be replaced through certain zone due to potential face instability' are well meaning - as maintaining the reamer pressure on the face helps stabilise the ground. However, the poor ground, with its falling blocks/wedges, is the cause of cutter dislodgment which results in the need to lower the reamer and replace the cutters. The purpose of the ground evaluation is to give reasonable assurance that the ground will remain intact so that you can drill through it. This includes an understanding of not only the geotechnical interpretations of the zones to be drilled, but also how they will interact within the drilling cycle.

As noted by Coombes et al. (2011), "while geotechnical parameters are easy to talk about, they are expensive to investigate and difficult to measure and then use to confidently predict stability, or instability. Experience and actual construction performance is often the best teacher". This reinforces the 
idea that the mining and geotechnical community should be sharing raise performance data to improve empirical raise stability assessment.

\section{$4 \quad$ Prominent large-diameter raiseboring examples}

\subsection{Introduction}

A listing of large single pass raiseboring projects was compiled by Hudd and Martin in 2010. Table 2 provides an update to their listing with additional prominent raiseboring projects completed after 2010. This list is not exhaustive, but it is intended to show the increased frequency of large-diameter raiseboring in recent years, especially in areas outside the RSA. It is believed that all the listed projects since 2007 have used the RVDS to maintain verticality.

Table 2 List of some of the largest completed single pass raiseboring projects

\begin{tabular}{|c|c|c|c|c|}
\hline Year & Location & Length (m) & Diameter (m) & Main rock types \\
\hline 1986 & Deelkraal-RSA & 1,036 & 6.1 & Norite \\
\hline 1988 & Frank Shaft - RSA & 1,033 & 5.8 & Norite \\
\hline 1993 & Turffontein - RSA & 1,102 & 4.5 & Norite \\
\hline 1997 & Phalaborwa - RSA & 923 & 5.7 & \\
\hline 1998 & Amandulbult - RSA & 877 & 5.52 & Norite \\
\hline 1998 & Impala I-RSA & 965 & 5.1 & Norite \\
\hline 1999 & Impala II - RSA & 784 & 5.8 & Norite \\
\hline 2000 & Bosjespruit - RSA & 180 & 7.1 & Dolerite \\
\hline 2007 & Red Lake - Canada & 694 & 5.52 & Basalt \\
\hline 2008 & Gwalia - Australia & 800 & 5.52 & Basalt \\
\hline 2010 & Cadia VR-4 - Australia & 930 & 6 & Volcanics \\
\hline 2011 & Westwood-Canada & 846 & 6 & \\
\hline 2012 & PT Freeport - Indonesia & 516 & 6 & \\
\hline 2012 & Northgate Shaft - Canada (Leg 1) & 455 & 5.5 & Volcanic and intrusive \\
\hline 2013 & Northgate Shaft - Canada (Leg 2) & 450 & 5.5 & Syenite \\
\hline 2014 & PT Freeport - Indonesia & 520 & 6 & \\
\hline 2014 & Cadia VR-9 - Australia & 681 & 6 & \\
\hline 2016 & Callie VR-6 - Australia & 800 & 5.5 & \\
\hline 2016 & PT Freeport - Indonesia & 507 & 6 & \\
\hline Current & Mindola Deeps - Zambia & $\sim 500 \times 4$ legs & 6.1 & \\
\hline 2016 & Synclinorium VR - Zambia (Leg 1) & 738 & 6.1 & \\
\hline Current & Synclinorium VR - Zambia (Leg 2) & 447 & 6.1 & \\
\hline 2017 & Northgate Shaft - Canada (Leg 3) & 508 & 5.5 & Meta-sediments \\
\hline
\end{tabular}

The remainder of Section 4 provides brief summaries of some interesting and prominent recent raiseboring projects to illustrate the opportunities that current raiseboring technology presents. 


\subsection{Northgate Shaft, Young-Davidson mine, Canada}

One of the most prominent bored hoisting shaft projects in North America over the past few years is the Northgate Shaft at the Young-Davidson mine near Matachewan, Ontario, Canada. A $5.5 \mathrm{~m}$ diameter hoisting shaft from surface down to approximately $900 \mathrm{~m}$ was completed in 2012-13 in two legs. The shaft is currently being deepened to approximately $1,500 \mathrm{~m}$ depth in the third raisebore leg. This project has been described in papers by Martin et al. (2012) and Hudd et al. (2014).

The basis for accepting the geotechnical risk of raise stability for this project included the long history of the nearby timber shaft which had stood unsupported for decades, as well as favourable ground conditions in nearby ramp development.

\subsection{Ventilation raises and secondary egress, Michigan, USA}

A new copper-nickel mine in Michigan began production as a ramp access mine in 2014 . Two $4.5 \mathrm{~m}$ diameter, $178 \mathrm{~m}$ long ventilation raises were successfully completed in 2013. The raises were developed in peridotite with an approximate UCS of $130 \mathrm{MPa}$. The RVDS was used for both raises.

It was decided to outfit the fresh air ventilation raise with a mechanised raise climber for use as secondary mine egress (McGuire et al. 2016). The boring went smoothly and resulted in stable walls as shown in Figure 4. Both raises remain in good condition after three years of use. A top-down mechanised raise climber was set up for installing ground support (screen and bolts) and furnishings (communications and power cables). The work platform was removed and an Alimak car installed as the egress conveyance.

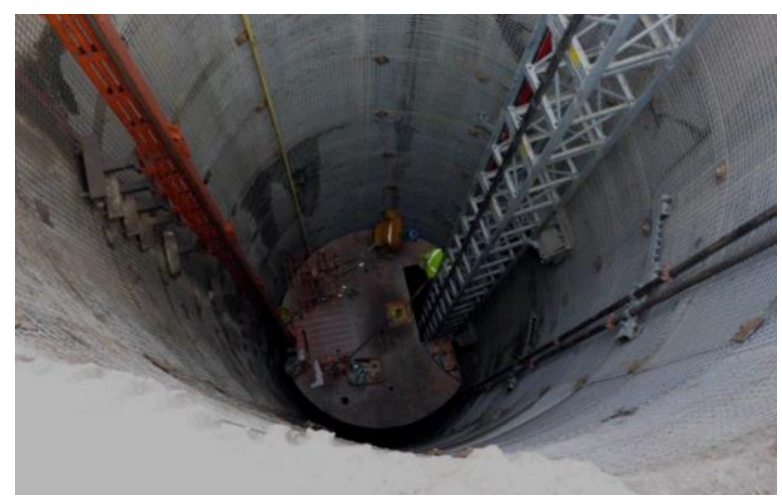

Figure 4 Secondary egress in a $4.5 \mathrm{~m}$ diameter raise - installing ground support from work deck showing smooth bored walls and tidy ground support (McGuire et al. 2016)

\subsection{Ventilation raise, western USA}

Though not a large-diameter raise by modern standards, this example provides an interesting case study from a geotechnical risk perspective. A ventilation raise, $3.5 \mathrm{~m}$ in diameter and $108 \mathrm{~m}$ long was to be developed at the base of a large, mature, open pit mine. The raise was located primarily in altered quartzite. A review of the raise stability using the M\&S Method indicated that the raise would not be stable. The site team, using site-specific experience, believed that the raise would be stable, and the project was undertaken. The raise was successfully reamed. Remote shotcrete was applied immediately following reaming, and the raise has reportedly performed well for over three years.

This example illustrates the importance of site-specific experience. An outside consultant, using the M\&S Method alone, would be unlikely to sanction the project. However, knowing the similar rock mass performance exposed in large pit slopes, and in limited underground horizontal development, provided further objective information indicating that the raise would be stable. 


\subsection{Ventilation raise, Australia}

One of the most important raiseboring projects to be completed in Australia was a $6 \mathrm{~m}$ diameter raise nearly $1,000 \mathrm{~m}$ long. It was drilled from surface through Paleozoic sedimentary and volcaniclastic rocks. Rock mass conditions were generally good to very good with unconfined rock strength of 80 to $120 \mathrm{MPa}$. The raise proved that long, large-diameter raises could be completed, given suitable rock conditions, in Australia.

\subsection{Ventilation raise, Red Lake, Canada}

In 2007, the first prominent, long, large-diameter raiseboring project was completed in the hard rock of the Canadian Shield at Red Lake, Ontario. A $5.52 \mathrm{~m}$ diameter, $694 \mathrm{~m}$ long raise was successfully bored primarily through hard basalt rocks. Some strong metasedimentary and weaker ultramafic rocks were also encountered. Canadian greenstone gold belts, such as Red Lake are recognised for geotechnically challenging zones of talc alteration. A talc zone was encountered in this raise, though without any raiseboring difficulties.

\subsection{Mindola Deep shaft, Zambia}

A current important application of large-diameter raiseboring is at the Mindola Deep project, part of Mopani Copper Mines' operations in Zambia's Copperbelt Province. Here, a 2,000 m deep hoisting shaft at $6.1 \mathrm{~m}$ diameter is being completed in four legs of $500 \mathrm{~m}$ each (Sidler 2014). Pilot holes, drilled using the RVDS, have been successful so far - with 1,470 m completed, a maximum deviation of $67 \mathrm{~mm}$ has been achieved (James 2017). Unlike the Young-Davidson shaft profiled in Section 4.2 which used rope guides, the Mindola Deep shaft will have steel guides installed (James 2017). The project is believed to be the deepest borehole hoisting shaft ever to be attempted.

In addition to the hoisting shaft at Mindola Deep, Mopani Copper Mines is currently undertaking a large-diameter ventilation shaft using the raiseboring method. The Synclinorium Shaft is also $6.1 \mathrm{~m}$ in diameter, and will be over $1,100 \mathrm{~m}$ deep when completed. The raise is being completed in two legs. The first leg, over $700 \mathrm{~m}$ long, has been successfully completed. The second leg, over $400 \mathrm{~m}$ long, is currently being excavated.

\section{Conclusions}

Raiseboring has undergone a steady evolution in the past 50 plus years so that large-diameter $(<5 \mathrm{~m})$ and long (up to $1,000 \mathrm{~m}$ ) single pass raises have now become common. Given these advances, mine planners now have the opportunity to consider raiseboring for their mine's large-diameter vertical development needs. This paper provides some guidance and considerations for these projects. There are four fundamental questions to be asked during the planning stage:

1. Is the size and length within current capabilities?

2. Is the ground suitable?

3. Do you have access at the bottom?

4. Can you handle the waste generated underground?

Questions 1, 3 and 4 should be relatively easy to answer. The second question, the assessment of ground suitability - the greatest project risk for raiseboring - is seldom a simple matter. This paper provides summary guidance for planning these projects, including for ground suitability, but it is only a synopsis. The reference list provides further basis for planning. For project success, it is suggested that mine planners make early contact with both knowledgeable raise drill operators and personnel with high familiarity and experience with mine ground conditions and performance when planning any large-diameter raiseboring projects. 


\section{Acknowledgement}

The author is grateful to the following raiseboring specialists: Lawrence Newnham at RUC Cementation (Kalgoorlie, Western Australia) and Dennis Martin and Glen Fallon at Cementation Canada Inc. (North Bay, Ontario) for sharing their wealth of knowledge and experience. Thank you to Alun Price Jones for both encouraging, reviewing and improving this paper, and to Cementation Canada Inc. for supporting its publication.

\section{References}

Barton, N, Lien, R \& Lunde, J 1974, 'Engineering classification of rock masses for the design of tunnel support', Rock Mechanics, vol. 6, pp. 189-236.

Bertuzzi, R \& Wallis, J 2008, 'Rock mass classification is only part of the answer to assess raise boring', Proceedings of the 10th AusIMM Underground Operators' Conference, The Australasian Institute of Mining and Metallurgy, Melbourne, pp. 191198.

Bieniawski, ZT 1989, Engineering Rock Mass Classifications, John Wiley \& Sons, New York.

Coombes, BM, Lee, MF \& Peck, WA 2011, 'Improving raisebore stability assessments and risk', Proceedings of the 2011 Canadian Institute of Mining, Metallurgy and Petroleum Conference and Exhibition, Canadian Institute of Mining, Metallurgy and Petroleum, Westmount.

Dengler, WR \& Brown, RS 1976, 'Borehole hoisting for shaft sinking and development at Brunswick Mining and Smelting Corporation Limited, Bathurst, New Brunswick', in R Robbins \& R Conlon (eds), Proceedings of the 1976 Rapid Excavation and Tunnelling Conference, Society of Mining Engineers of the American Institute of Mining, Metallurgical, and Petroleum, New York. pp. 169-181.

Ferreira, PH 2005, 'Mechanised mine development utilising rock cutting and boring through raise and blind boring techniques', Proceedings of the Third Southern African Conference Base Metals, Southern African Institute of Mining and Metallurgy, Johannesburg, pp. 297-313.

Goodman, WM, Plumeau, DB, Voigt, JO \& Gnage, DJ, 2009, 'The history of room and pillar salt mines in New York State', in S Zuoliang (ed.), Proceedings of the 9th International Symposium on Salt, vol. 2, Gold Wall Press, Beijing, pp. 1239-1248.

Harrison, GP, Green, NE \& Bennett, WE 1972, 'Some aspects of the art of raise boring', in K Lane \& L Garfield (eds), Proceedings of the 1972 Rapid Excavation and Tunnelling Conference, Society of Mining Engineers of the American Institute of Mining, Metallurgical, and Petroleum, New York, pp. 1161-1183.

Hudd, PS \& Martin, D 2010, 'Large diameter raise boring in hard rock - an overview, its applications and considerations', Proceedings of the 2010 Canadian Institute of Mining, Metallurgy and Petroleum Conference and Exhibition, Canadian Institute of Mining, Metallurgy and Petroleum, Westmount.

Hudd, PS, Guimond, L \& Bartlett, R 2014, 'The successful design and construction of an 8,000 tpd production hoisting facility using a large diameter raise bored shaft', Proceedings of the 2014 Canadian Institute of Mining, Metallurgy and Petroleum Conference and Exhibition, Canadian Institute of Mining, Metallurgy and Petroleum, Westmount.

Hutchinson, DJ \& Diederichs, MS 1996, Cablebolting in Underground Mines, BiTech Publications, Vancouver.

James, N 2017, 'Completion of Mindola shaft expected in 2019', Mining Weekly, Creamer Media, Johannesburg, viewed 26 June 2017, http://www.miningweekly.com/print-version/completion-of-mindola-shaft-expected-in-2018-2017-01-12

Lauffer, H 1988, 'Zur Gebirgsklassifizierung bei Frasvortrieben', Felsbau, vol. 6, no. 3, pp. 137-149.

Martin, DG, Hunt, R \& Price Jones, A 2012, 'New opportunities for mine planners - large diameter borehole hoisting systems', Proceedings of the Third International Conference on Shaft Design and Construction, Institute of Materials, Minerals and Mining, London.

McCracken, A \& Stacey TR 1989, 'Geotechnical risk assessment for large-diameter raise-bored shafts', Proceedings of the Second International Conference on Shaft Design and Construction, Institute of Materials, Minerals and Mining, London.

McGuire, C, Witow, D \& Connors, C 2016, 'Operating and maintenance experience for a mechanized raise climber in a metal mining egress application', Proceedings of the 2016 Maintenance, Engineering and Reliability/Mine Operators (MEMO) Conference, Canadian Institute of Mining, Metallurgy and Petroleum, Westmount.

Nadon, MR \& Kelly, MJ 1991, 'Bore or blast - Alimak raising and raise boring which method for what conditions', Engineering and Mining Journal, July 1991, pp. 34-36.

New South Wales Mine Safety 2013, Guideline for Raiseboring Operations, NSW Mine Safety, Sydney.

Oosthuizen, M 2004, 'Large diameter vertical raise drilling and shaft boring techniques an alternative to conventional shaft sinking techniques', Proceedings of the 2004 South African Institute of Rock Engineering Symposium, South African Institute of Rock Engineering, Stilfontein, pp. 149-163.

O'Toole, D \& Sidea, D 2005, 'Recent development in Australian shaft excavation practice - raise bored shafts in highly stressed rock', Proceedings of the 9th AusIMM Underground Operators' Conference, The Australasian Institute of Mining and Metallurgy, Melbourne, pp. 29-32.

Peck, WA \& Lee, MF 2007, 'Application of the Q-System to Australian underground metal mines', in C Mark, R Pakalnis \& R Tuchman (eds), Proceedings of the International Workshop on Rock Mass Classification in Underground Mining, National Institute for Occupational Safety and Health, Cincinnati, pp. 129-140. 
Peck, WA \& Lee MF 2008, 'Stability of raise bored shafts in Australian mines', in Proceedings of the 13th Australian Tunnelling Conference, The Australasian Institute of Mining and Metallurgy, Melbourne, pp. 331-337.

Peck, WA, Coombes, B \& Lee MF 2011, 'Fine-tuning raisebore stability assessments and risk', Proceedings of the 11th AusIMM Underground Operators' Conference, The Australasian Institute of Mining and Metallurgy, Melbourne, pp. 215-226.

Schrami, E \& Schimper 2002, 'Emergency egress/ventilation raise innovations in directional raise boring \& remote shotcrete application', Proceedings of the 2002 Canadian Institute of Mining, Metallurgy and Petroleum Conference and Exhibition, Canadian Institute of Mining, Metallurgy and Petroleum, Westmount.

Sidea, D \& Pfitzner, M 2012, 'Raiseboring... how well do you know your rocks', presented at Vertical Development Workshop, Eastern Australia Ground Control Group, Hobart.

Sidler, V 2014, 'Mopani Deeps reaches new heights at greater depths', Mining Review Africa, no. 3, pp. 32-34.

Stack, B 1982, Handbook of Mining and Tunnelling Machinery, John Wiley \& Sons, Chichester.

Stacy, TR \& Harte, ND 1989, 'Deep level raise boring - prediction of rock problems', in V Maury \& D Fourmaintraux (eds), Rock at Great Depth, A.A. Balkema, Rotterdam, pp. 583-588. 
